\title{
Seismic hazard assessment of Western Coastal Province of Saudi Arabia: deterministic approach
}

\author{
Faisal Rehman · Sherif M. El-Hady • Ali H. Atef • \\ Hussein M. Harbi
}

Received: 17 April 2016/ Accepted: 4 September 2016/Published online: 18 October 2016

(C) The Author(s) 2016. This article is published with open access at Springerlink.com

\begin{abstract}
Seismic hazard assessment is carried out by utilizing deterministic approach to evaluate the maximum expected earthquake ground motions along the Western Coastal Province of Saudi Arabia. The analysis is accomplished by incorporating seismotectonic source model, determination of earthquake magnitude $\left(M_{\max }\right)$, set of appropriate ground motion predictive equations (GMPE), and logic tree sequence. The logic tree sequence is built up to assign weight to ground motion scaling relationships. Contour maps of ground acceleration are generated at different spectral periods. These maps show that the largest ground motion values are emerged in northern and southern regions of the western coastal province in Saudi Arabia in comparison with the central region.
\end{abstract}

Keywords Earthquakes - Seismic hazard - Logic tree Peak ground acceleration

\section{Introduction}

A major reason for anxiety arises from the increase of seismic vulnerability of most urban structures especially in

Present Address:

F. Rehman $(\bowtie)$

Department of Earth Sciences, University of Sargodha, Sargodha, Pakistan

e-mail: faisal.rehman@uos.edu.pk

S. M. El-Hady · A. H. Atef · H. M. Harbi

Geophysics Department, King Abdulaziz University, Jeddah, Saudi Arabia

S. M. El-Hady

Earthquake Department, National Research Institute of Astronomy and Geophysics, Helwan, Egypt developing countries (Re 2000). The most important element in the seismic design of the structure and its vulnerability assessment against the earthquake damage is ground motion vibrations. These parameters are evaluated through probabilistic seismic hazard assessment (PSHA) or deterministic seismic hazard assessment (DSHA) approaches (Waseem et al. 2013). The DSHA depends on selected earthquake scenario, specific ground motion probability, and closest distance to the site of interest. However, PSHA deals with numerous scenarios for earthquake and ground motion probabilities (Lin and Baker 2011).

In DSHA investigation, a maximum credible earthquake is supposed to occur at the closest distance to the site of interest. Meanwhile, the occurrence of earthquake probability during the specific period of exposure is neglected (Tavakoli et al. 2013). It must be noted that there is no commonly accepted deterministic seismic hazard analysis approach that is applicable to all parts of the world as it is experienced in assorted ways in different parts of the world. The traditional DSHA methodology delineates the seismic source or sources that might affect the site of concern and then computes the maximum possible earthquake magnitude for each of these sources. By considering each of these maximum earthquakes placed at a location that put the earthquake at the minimum possible distance to the site, the ground motion is expected, mostly, applying an empirical attenuation relation.

Previous studies, about seismic hazard assessment along Western Coastal Province of Saudi Arabia are limited and focus only on PHSA [e.g., Al-Amri (2013) and Al-Arifi et al. (2013)]. Recently, there are few published researches related to DSHA that are applied to some local cities located within Western Coastal Province of Saudi Arabia [e.g. Almadani et al. (2015)]. Yet there is no publication which accounts for the mapping of DSHA that could cover whole Western Coastal regions of Saudi Arabia. 
The deterministic approach is subject to the epistemic and aleatory uncertainties (Stepp et al. 2001). In this research, the epistemic uncertainties are treated by taking alternatives for the ground motion prediction equations, which in concern link several different assessments of the ground motion. The aleatory uncertainties are related to various input parameters used to describe the seismicity and the ground motion prediction equation.

In the present study, DSHA is carried out along the whole Western Coastal Province of Saudi Arabia (Fig. 1). The grid spacing for regional studies is usually $50 \mathrm{~km} \times$ $50 \mathrm{~km}$ or half degree (latitude or longitude) e.g., (Deif et al. 2013; Mohamed et al. 2012). A grid of 50 by $50 \mathrm{~km}$ (about 155 points) is selected along the eastern coast of Red Sea. For each point, the DSHA is evaluated with associated uncertainty and adopted by a variable logic tree (essentially due to change in distance between points of the grid). In current study, the used methodology is proposed by Campbell (2005) and applied by Deif et al. (2013, 2009). This methodology deals with the uncertainty problem and provides ground motion at different percentile levels at various spectral periods. This provides great flexibility to

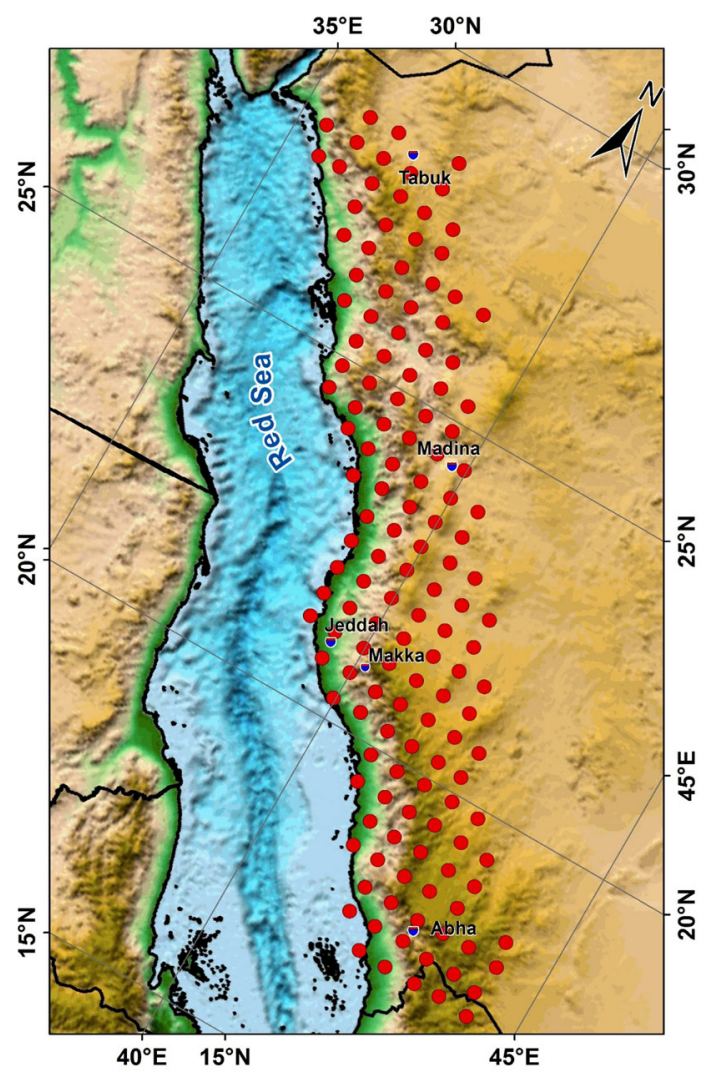

Fig. 1 Location map for the hazard assessment grid point along the western coast of Saudi Arabia the engineer to select the appropriate input ground motions for selected site.

\section{Crustal structure and regional seismicity}

Lithospheric structure and composition of the Arabian Plate are constructed using a broad choice of geophysical data (Stern and Johnson 2010). The Arabian Plate has a varying crustal thicknesses range. It varies from 22 to $53 \mathrm{~km}$ across the plate from west to east (Fnais et al. 2013). The variation is at modest amount in central Arabia ranging from 32 to $46 \mathrm{~km}$ in west to $35-50 \mathrm{~km}$ in east (Al-Damegh et al. 2005; Rodgers et al. 1999). The crustal thickness approaches $43 \mathrm{~km}$ at east of the Central Arabian Magnetic Anomaly (CAMA) and $38 \mathrm{~km}$ thick in western part of CAMA. There is a considerable crustal discontinuity in lateral direction beneath the CAMA, causing velocity increment around $0.2 \mathrm{~km} / \mathrm{s}$ in northeast (Gettings et al. 1986).

The dominant mafic composition of the Arabian Shield is the reason for high crustal velocities in lower crust. The studies of entire shield by surface wave designated the Moho's depth to be at 41-46 km (Mokhtar 2004; Mokhtar et al. 2001). The crust composition, which is inferred from velocity structure, indicates lower mafic crust overlying by upper felsic crust, having low velocities (Stern and Johnson 2008).

The Arabian plate seismicity is clustered and controlled along its major tectonic borders, Red Sea rifting, Dead Sea transform fault, Zagros fold and thrust belt, Biltis thrust, and Makran subduction zone. Seismic activities in the vicinity of the study area are mainly controlled and narrowed along the Red Sea rifting, Gulf of Aqba, and Gulf of Aden (Fig. 2). The seismic activity is concentrated along Red Sea axial trough (Al-Malki and Al-Amri 2013).

\section{Methodology}

The estimation of ground motion parameters is carried out through seismic hazard assessment (SHA) at a site of interest for seismic design (Hashemi et al. 2013). SHA analysis depends on seismic activity and attenuation relations (Dowrick 2009). However, DSHA is restricted to a specific earthquake scenario.

The methodology for the current study followed Campbell (2005) procedure for the DSHA which is described in context to the study area as below:

1. Identification of the seismogenic sources having possible impact on Western Coastal Provinces of Saudi Arabia. 


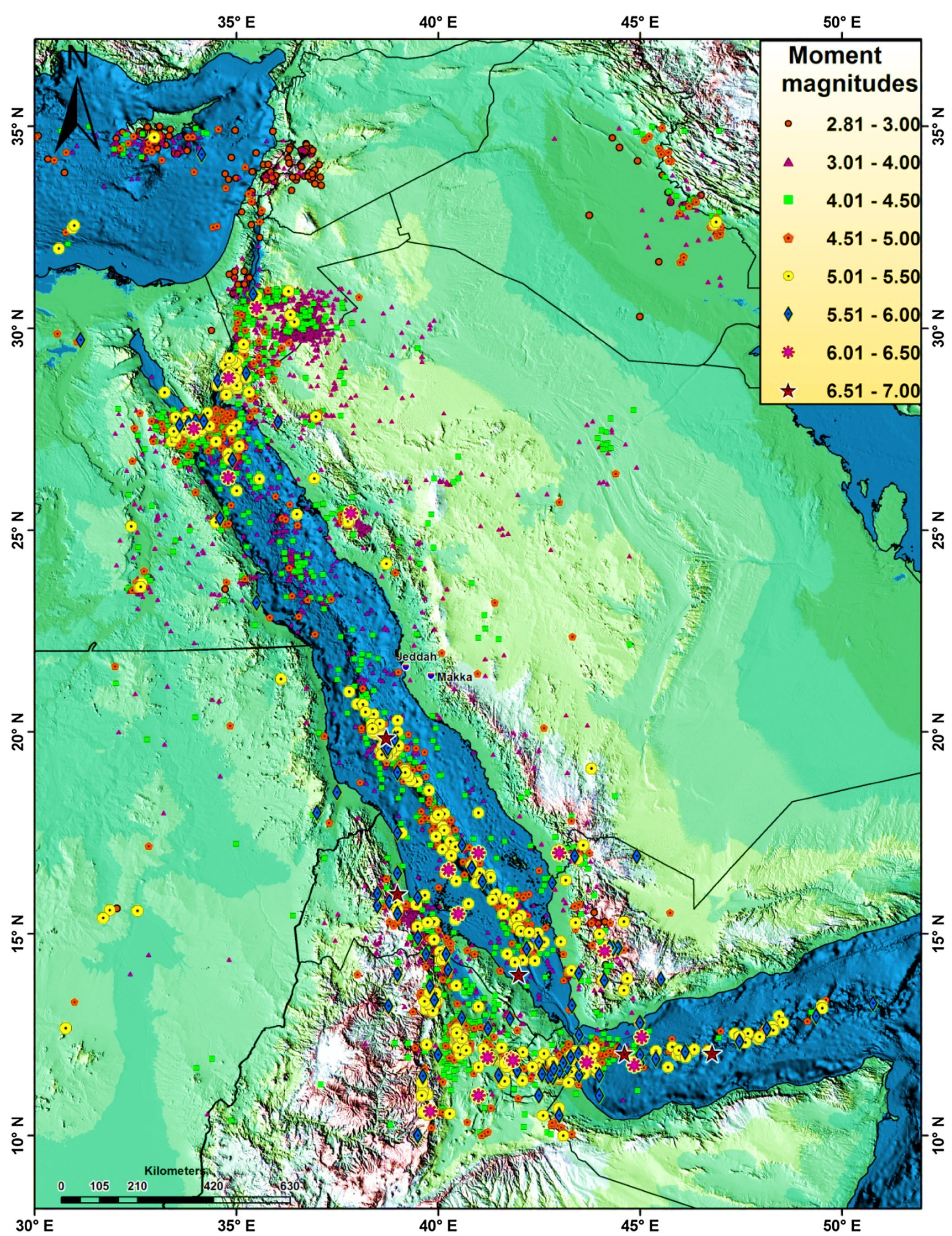

Fig. 2 Instrumental seismicity map of the Arabian Shield and its surrounding for the period from 1900 to 2014 for magnitude 2.81 and above 
2. Calculation of maximum earthquake $\left(M_{\max }\right)$ for each seismic source zone using earthquake catalogue and Gutenberg and Richter relationship.

3. Selection of a specific set of earthquake magnitude and distance scenarios.

4. Selection of appropriate set of attenuation laws (ground motion scaling relationships).

5. Incorporation of uncertainties using logic tree.

6. Calculation of the median ground motion for each scenario.

7. Delineate the largest median value among calculated median ground motions.

8. Calculate fractile (percentile) largest median value.

In the current study, the logic tree is utilized to capture uncertainty. Thus the following structure of current methodology for DSHA is build up; identification of seismic sources, calculation of maximum credible earthquake magnitude $M_{\max }$, selection of appropriate ground motion attenuation equations, and finally building logic tree to assign weight to GMPE.

\section{Identification of seismogenic sources}

The seismic source delineation is a major key parameter in hazard assessment (Vipin and Sitharam 2013). The seismogenic source characterizations follow historical and recent seismicity, seismicity pattern, seismogenic potential of active faults (Meletti et al. 2008). The seismogenic source model is identified and delineated by consideration from ancient times and current seismicity, tectonic and geological setting, crustal tomographic studies, crustal heat flow measurements, and current hazard studies (Al-Amri 2013; Al-Arifi et al. 2013; Al-Damegh et al. 2005; AlMalki and Al-Amri 2013; Ares 2010; Burkhard and Grünthal 2009; Pailoplee et al. 2010). In current study, seismogenic source model by Rehman (2016) is utilized to carry out hazard assessment process (Fig. 3).

\section{Earthquake catalogue}

One of the most important products of seismology is earthquake catalogue which provides a broad dataset in earthquake events. This can be used in various analyses associated with seismicity and seismotectonic, hazard assessment, and physics of earthquake. The hazard parameters are determined well if the catalogue has longer time coverage (Woessner and Wiemer 2005). A catalogue is a basic requirement for seismicity analysis in space-time volume, and in SHA (Gupta et al. 2012; Leonard et al. 2011).

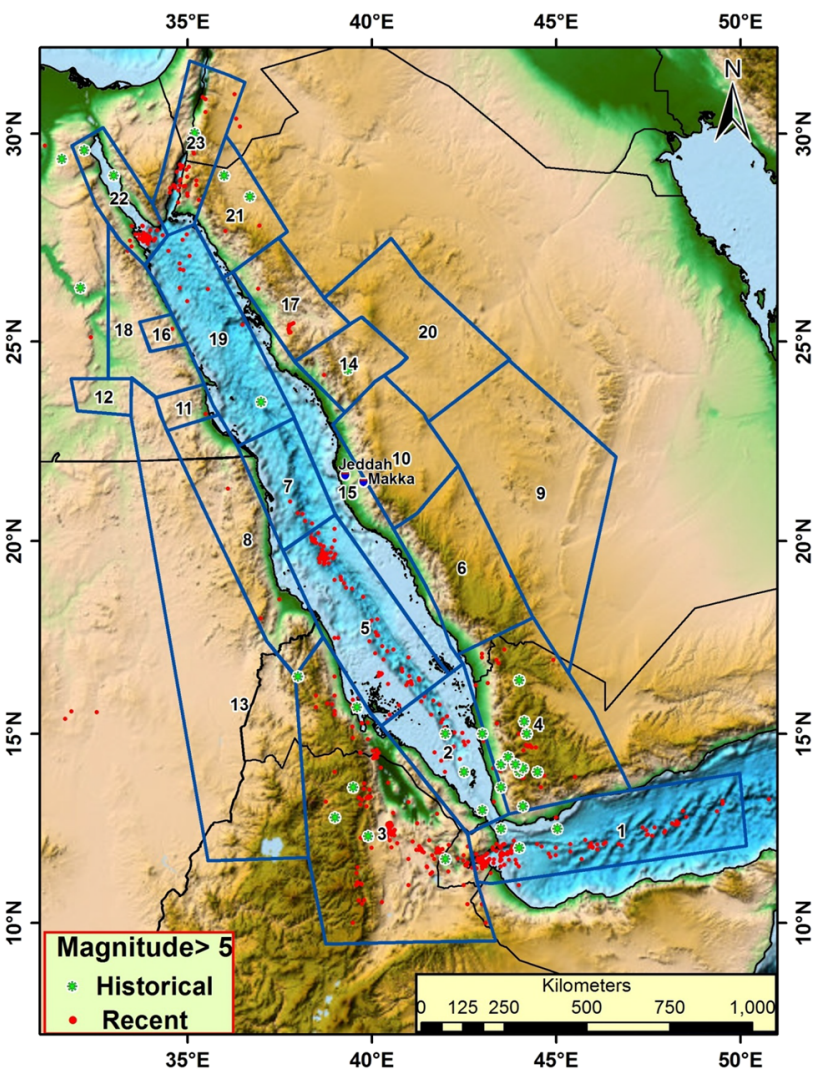

Fig. 3 Seismogenic source model (Rehman 2016)

In current study, the earthquake catalogue is compiled for spatial region extending from $15^{\circ}$ to $35^{\circ} \mathrm{N}$ and $29^{\circ}$ to $47^{\circ} \mathrm{E}$ and include events from magnitude 3 and above from 827 to 2013 AD. This catalogue is used to characterize seismicity of study area. It is compiled by combining information from different sources which include

- An earthquake catalogue provided by Dr. Abdullah M.S. Al-Amri (Personal Communication).

- The International Seismological Center online bulletin (http://earthquake.isc.ac.uk/).

- Preliminary determination of epicenters (PDE), online bulletin provided by the National Earthquake Information Center (NEIC) (http://earthquake.usgs.gov/earth quakes/).

- Incorporated research institutes for seismology online bulletin (http://www.iris.edu/SeismiQuery/sq-events. $\mathrm{htm})$.

- European Mediterranean Seismological Center (EMSC) (http://www.emsc-csem.org/Earthquake/).

- National Research Institute of Astronomy and Geophysics (NRIAG) bulletins (http://www.nriag.sci.eg/).

Poirier and Tahir (1980), Badawy (1999), Ambraseys et al. (2005a, b), Ambraseys et al. (1995, 2009), Guidoboni et al. (1994), and Guidoboni and Comastri (2005). 


\section{Completeness magnitude $\left(M_{\mathrm{c}}\right)$}

The completeness magnitude $\left(M_{\mathrm{c}}\right)$ is defined theoretically as the lowest magnitude at which $100 \%$ of earthquakes are detected in space-time volume. The precise estimation of $M_{\mathrm{c}}$ is critical because higher values of $M_{\mathrm{c}}$ lead to undersampling, and too low values are erroneous. Mainly catalogue-based and network-based techniques are applied for $M_{\mathrm{c}}$ estimation (Mignan and Woessner 2012). Magnitude of completeness is a basic requirement to model seismicity in an area. The maximum curvature technique is mainly used (Wiemer and Wyss 2000) for the completeness magnitude.

In current study, $M_{\mathrm{c}}$ for each seismogenic source zone is calculated using maximum curvature technique. The Fig. 4 is an example of $M_{\mathrm{c}}$ calculation for one zone.

\section{Gutenberg and Richter relationship (G-R)}

The seismicity of the seismic source zone is described by the means of famous recurrence relationship termed as G-R relationship.

$\log N=a-b M$,

$N$ represents the earthquakes of specific magnitudes $(M)$ or larger per year, $a$ is activity rate and defines the intercept of the above equation at $M=0$. The factor $b$ is the slope which depicts the comparative proportion of small and large magnitudes.

The Gutenberg and Richter (1944) relationship introduces an impractical supposition in which the largest size

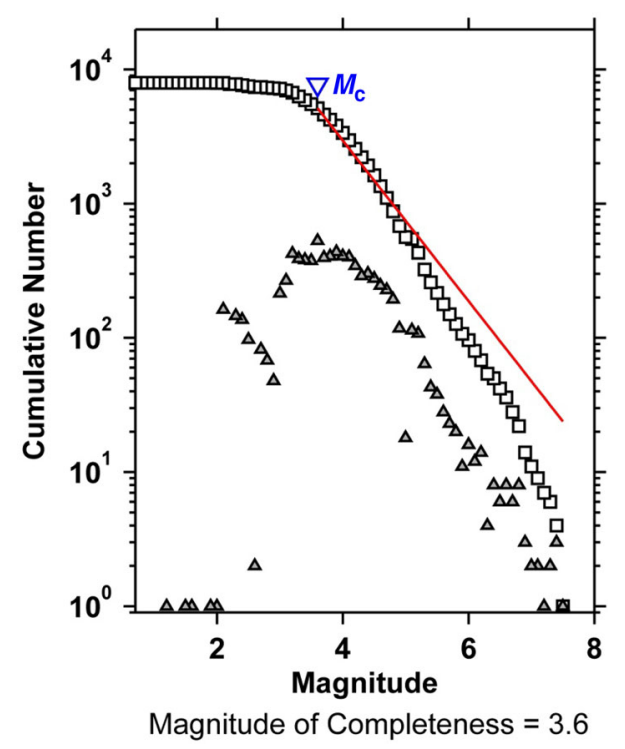

Fig. 4 Maximum curvature technique for completeness magnitude determination possible earthquake in any zone being studied, is unrestrained and unconnected toward seismotectonic setting. Kijko and Sellevoll (1989, 1992) extended the GutenbergRichter equation from data that contain large historical events and recent observation with that of different quality and heterogeneity. In current study, the $b$ values are calculated using Kijko and Sellevoll (1992) approach for each zone (Table 1).

\section{Maximum magnitude $\left(M_{\max }\right)$}

Another most important parameter beside recurrence parameters is maximum expected magnitude $\left(M_{\max }\right)$. The SHA is strongly influenced by the choice of $M_{\max }$. The $M_{\max }$ can be estimated using either deterministic or probabilistic approach. Deterministic approach comprises empirical regression relationships between the magnitude and various tectonic and fault rupture parameters, however the probabilistic approach involves extreme value statistics (Gupta 2002).

Table $1 M_{\max }$ and $b$ values for each seismogenic source zone

\begin{tabular}{lllllll}
\hline Zone no. & $M_{\max }$ & & & & $b$ values & \\
\cline { 2 - 3 } \cline { 6 - 7 } & Kijko & Error & Obs & & Kijko & Error \\
\hline 1 & 6.62 & 0.50 & 6.60 & 0.94 & 0.02 \\
2 & 6.66 & 0.50 & 6.60 & 1.06 & 0.03 \\
3 & 6.95 & 0.52 & 6.80 & 1.13 & 0.02 \\
4 & 6.45 & 0.50 & 6.40 & 0.99 & 0.03 \\
5 & 6.79 & 0.22 & 6.70 & 0.75 & 0.03 \\
6 & 6.00 & 0.54 & 5.50 & 0.94 & 0.07 \\
7 & 5.47 & 0.26 & 5.30 & 1.01 & 0.05 \\
8 & 6.30 & 0.54 & 5.80 & 0.85 & 0.07 \\
9 & 5.30 & 0.54 & 4.80 & 0.98 & 0.07 \\
10 & 5.53 & 0.50 & 5.00 & 0.99 & 0.07 \\
11 & 4.72 & 0.23 & 4.60 & 1.11 & 0.06 \\
12 & 5.35 & 0.32 & 5.10 & 0.97 & 0.05 \\
13 & 4.99 & 0.53 & 4.90 & 0.99 & 0.07 \\
14 & 5.84 & 0.52 & 5.70 & 0.98 & 0.07 \\
15 & 4.40 & 0.22 & 4.30 & 1.04 & 0.07 \\
16 & 4.86 & 0.26 & 4.70 & 1.13 & 0.06 \\
17 & 6.20 & 0.54 & 5.70 & 1.00 & 0.06 \\
18 & 5.19 & 0.35 & 4.90 & 1.11 & 0.06 \\
19 & 5.87 & 0.26 & 5.70 & 1.27 & 0.03 \\
20 & 5.52 & 0.50 & 5.00 & 1.06 & 0.07 \\
21 & 7.32 & 0.59 & 7.00 & 1.18 & 0.04 \\
22 & 6.69 & 0.51 & 6.60 & 1.19 & 0.03 \\
23 & 7.33 & 0.50 & 7.20 & 1.13 & 0.03 \\
\hline & & & & &
\end{tabular}


In current study, $M_{\max }$ for each seismogenic source zone is calculated using methodology proposed by Kijko (2004) based on observed seismicity. This method is designed for the calculation of the maximum earthquake magnitude, $M_{\max }$, for a seismogenic source zone. This technique is based upon broad equation for the estimation of $M_{\max }$, which is very flexible. This equation is applicable to the following three different scenarios:

- Distribution of earthquake magnitude follows doubly truncated Gutenberg-Richter relation.

- Moderate deviations occur from the Gutenberg-Richter relation for empirical magnitude distribution.

- There is no specific form of magnitude distribution assumed.

The first two solutions of the generic equation are parametric and the third solution non-parametric. The $M_{\max }$ values calculated for each seismogenic source zone are described in Table 1.

\section{Ground motion scaling relationships}

The ground motion scaling relationships are functions of seismological parameters which include earthquake magnitude, source to site distance, and site conditions (Atkinson and Boore 1995; Peruš and Fajfar 2009; Yazdani and Kowsari 2013). Joyner and Boore (1981) postulated functional form to derive these empirical relationships. The geometrical spreading for all distances is accounted in this functional form (Ambraseys et al. 2005a; Ambraseys et al. 1996; Boore et al. 1997; Sabetta and Pugliese 1987; Smith et al. 1996). The selection of GMPE is accomplished preliminarily from a list of available equations.

The selection and rejection criteria for a GMPE in this study are based upon Cotton et al. (2006) guidelines. The key consideration for GMPE selection/rejection is as described below:

- Irrelevant tectonic regime,

- Insufficient dataset,
- Model is not yet published in peer-reviewed journal,

- Unsuitable frequency range for engineering applications, and

- Inappropriately regression analysis or regression coefficients misjudged.

Six different ground motion scaling relations are selected in accordance to Cotton et al. (2006) guidelines, which fulfill the tectonic conditions of the study area. These models include Abrahamson and Silva (1997), Campbell and Bozorgnia (2003), Sadigh et al. (1997), Atkinson and Boore (1995), (Boore et al. 1997) and one next generation attenuation equation by Campbell and Bozorgnia (2008).

\section{Logic tree}

The logic tree comprised several branches which portray confidence on different input parameters. Weight is assigned to each parameter according to the confidence level on each input (Abrahamson and Bommer 2005; Bommer 2002; Bommer and Scherbaum 2008). In current study, logic tree framework is utilized to incorporate several GMPE. The GMPE are assigned different weights in accordance with applicability of each model with respect to source-site distance. The source to site distance is divided into three ranges 0-200, 200-600, and 600-1000 km. Maximum weight is assigned to next generation attenuation model (Fig. 5).

\section{Results and discussion}

The DSHA is carried out with EzFrisk $7.52^{\mathrm{TM}}$ program and ground motion acceleration values are calculated in $\mathrm{cm} / \mathrm{s}^{2}$ at bedrock. The deterministic response spectrum is generated for MEAN and 0.84 fractile. The maps for MEAN and 0.84 fractile at peak ground acceleration (PGA), $0.1,1$, and 2 s spectral periods are generated (Figs. 6, 7, 8, 9, 10, 11, 12, 13). 


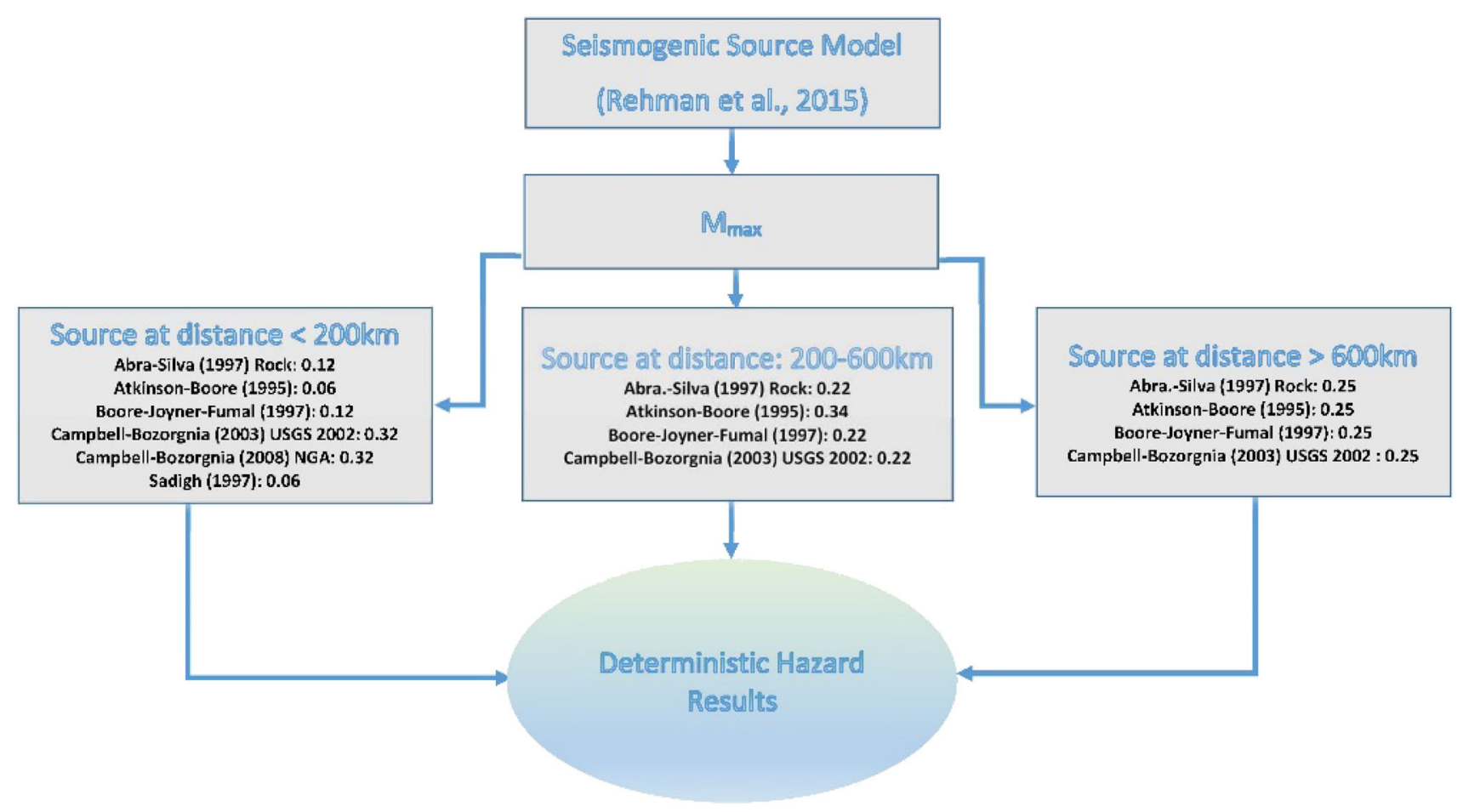

Fig. 5 Logic tree to incorporate various GMPE

The ground acceleration values are extremely high in northern part of the study area. The possible explanation for such acceleration is because of close proximity of northern part of study area to seismogenic sources 19, 21 22, and 23 (Fig. 3). The ground acceleration decreases toward central part where moderate acceleration values are present. However, the moderate values can be categorized into two distinct behaviors for accelerations (Figs. 5, 6, 7, 8 ). The values for ground acceleration are comparably low for shoulder area along the Red Sea coast as compared to its eastern part. The controlling source for this area is Zone 7 and Zone 15, which have low seismicity. However, the eastern parts of central area are controlled by higher seismicity zones than western part (Zones 6, 10, and 14). At southern part of the study area high ground acceleration behavior is observed. The controlling sources for this part of the study area are Zones 1, 2, 4, and 5 .

\section{Conclusions}

The deterministic approach actually considers the worst case ground motion. The worst case ground motion affects the design and cost of building. These ground motion spectra generated are used as essential input parameters for the upgradation of design parameters for local regulatory 


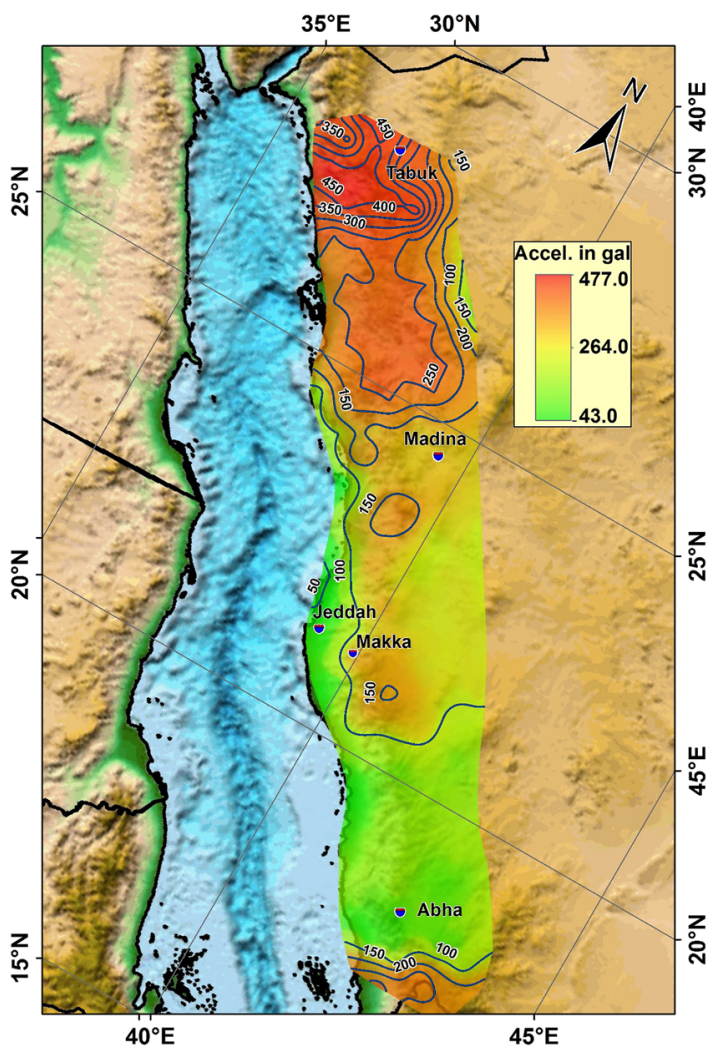

Fig. 6 MEAN peak ground acceleration map

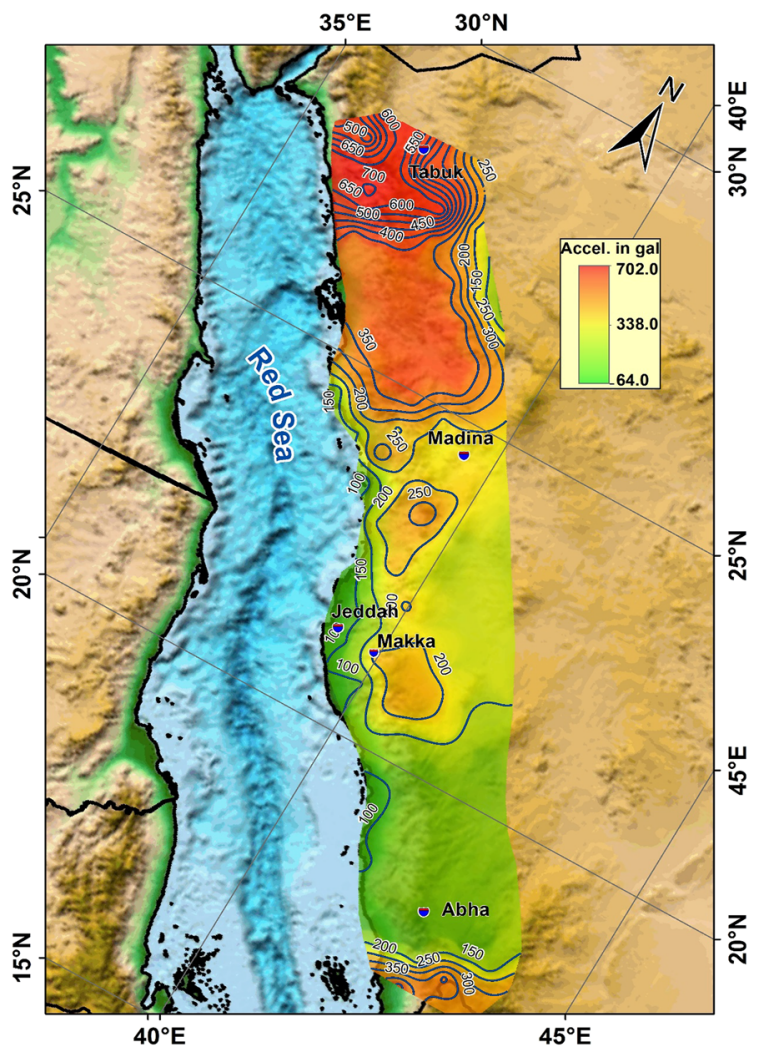

Fig. 70.84 fractile peak ground acceleration map

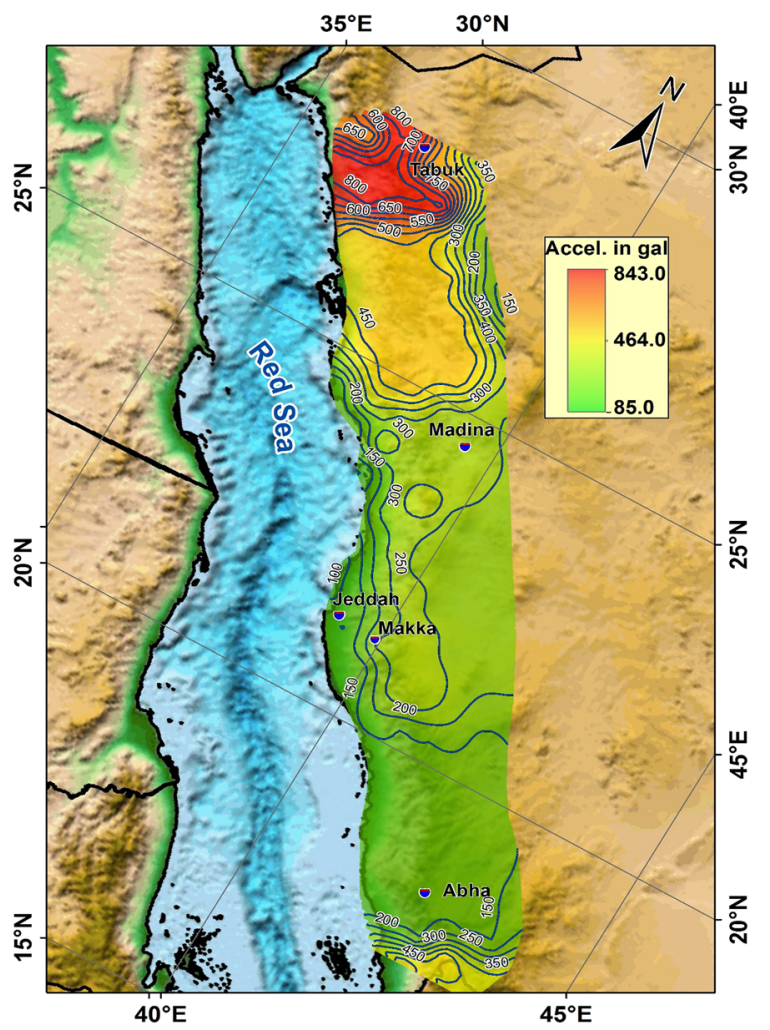

Fig. 8 MEAN acceleration map at $0.1 \mathrm{~s}$

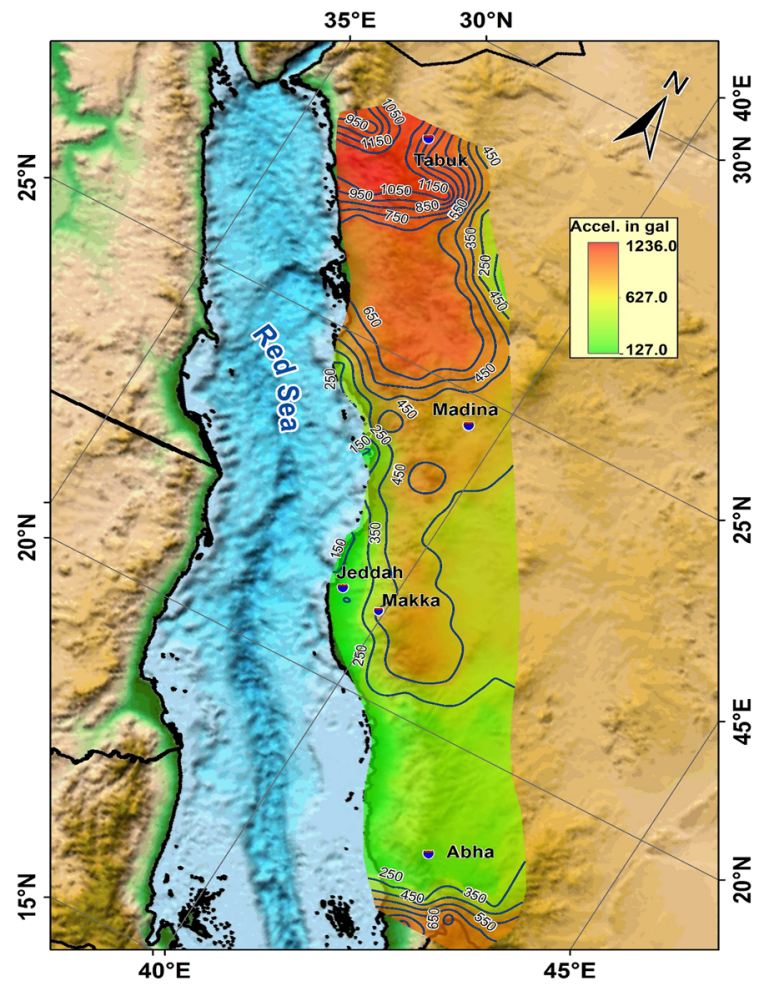

Fig. 90.84 fractile acceleration map at $0.1 \mathrm{~s}$ 


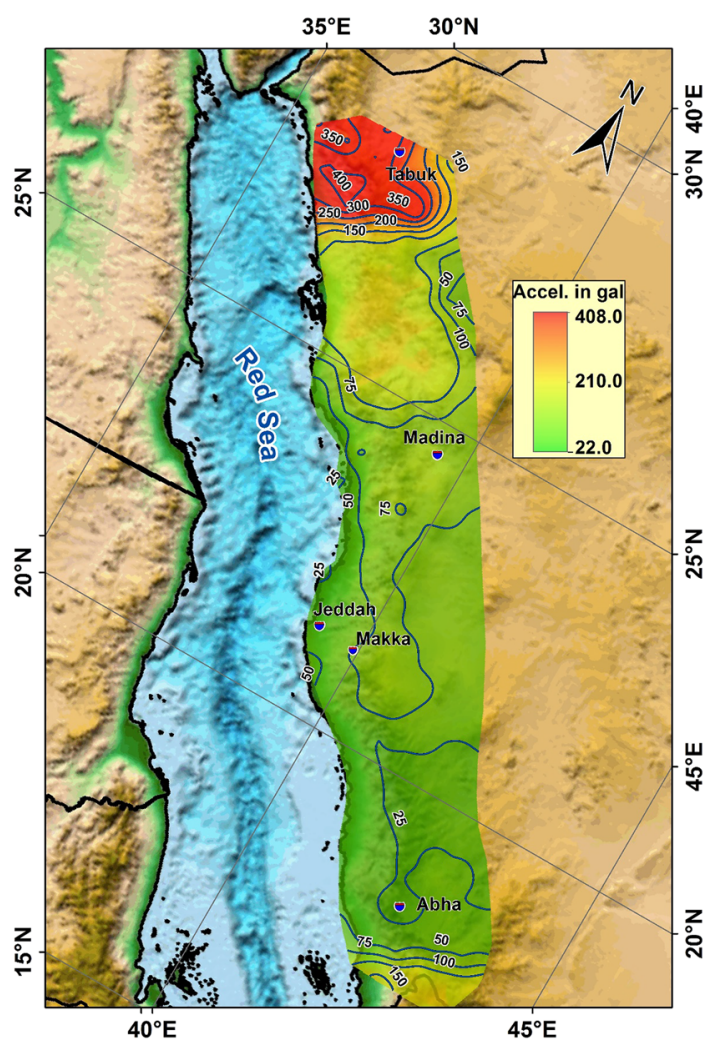

Fig. 10 MEAN acceleration map at $1 \mathrm{~s}$

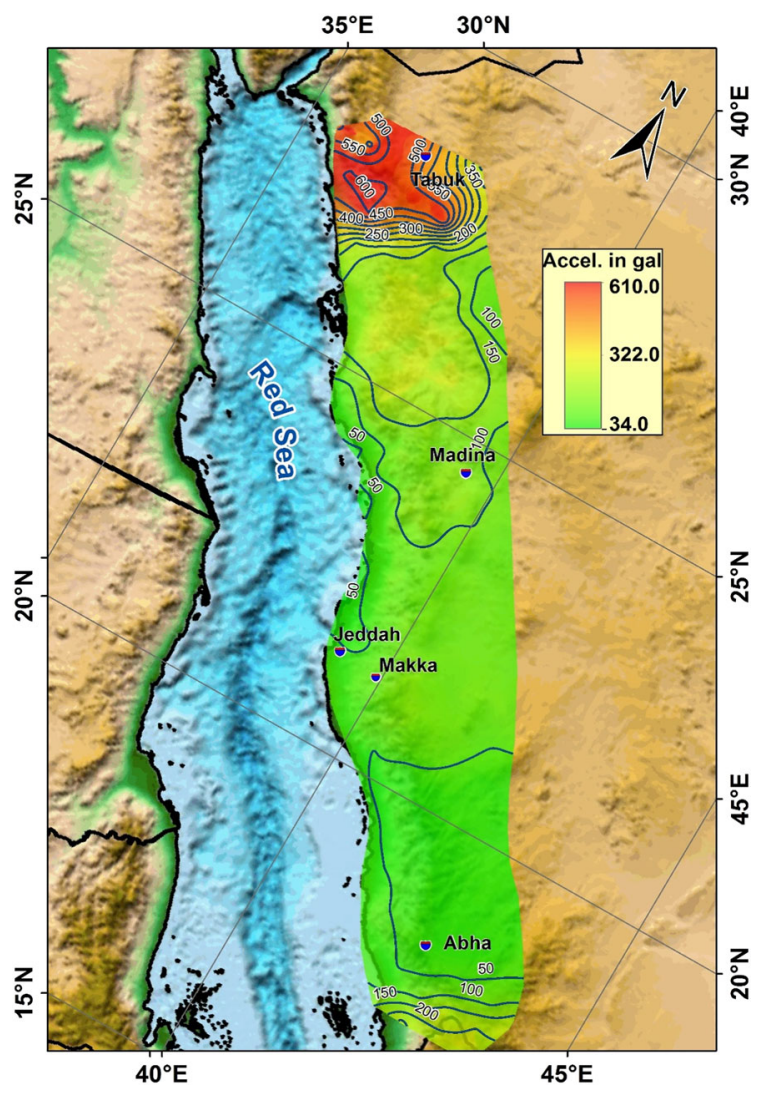

Fig. 110.84 fractile acceleration map at $1 \mathrm{~s}$

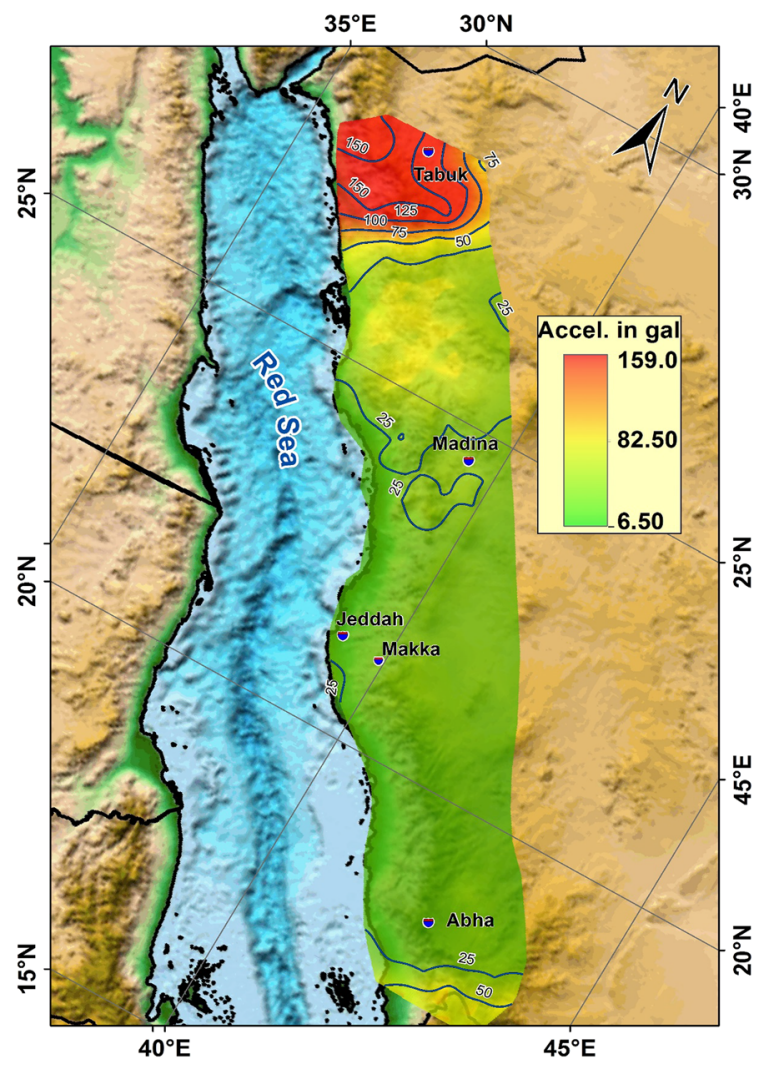

Fig. 12 Mean acceleration map at $2 \mathrm{~s}$

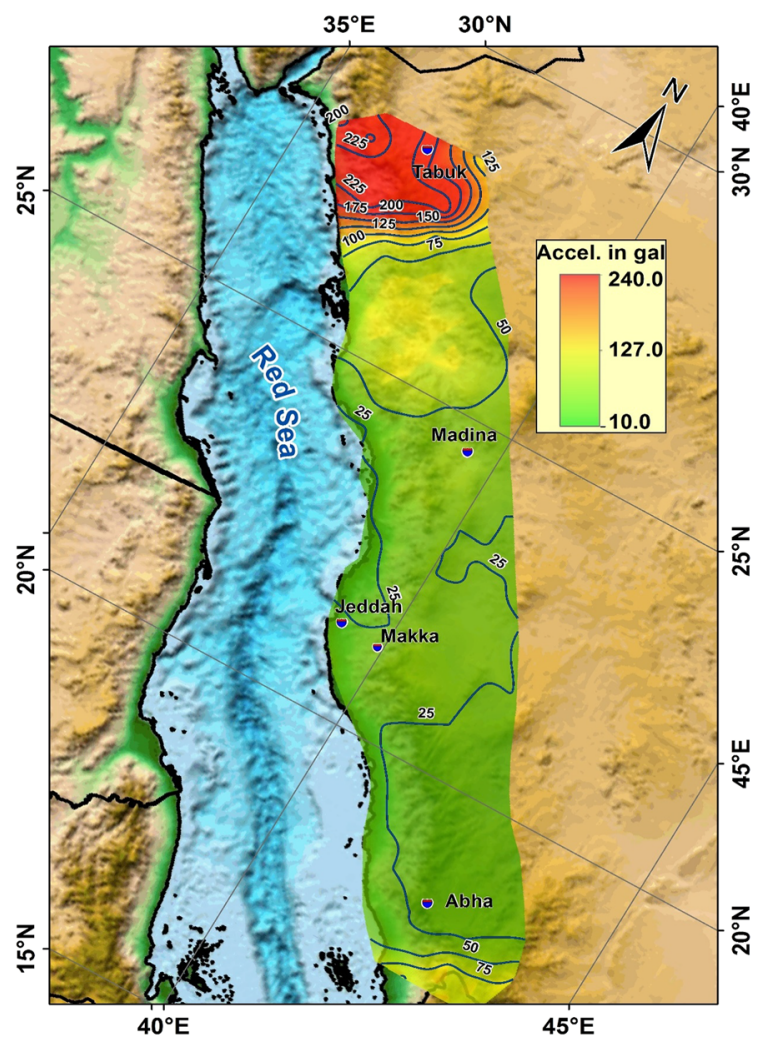

Fig. $1384 \%$ fractile acceleration map at $2 \mathrm{~s}$ 
requirements in accordance with international standards. The design parameters are dependent on the local geology and local site soil conditions. In the current study we calculated ground motion at bedrock. However, the effect of soil must be taken into consideration for local site-based design parameters.

The DSHA technique is utilized to determine maximum expected ground acceleration for western coastal regions of Saudi Arabia. This research concludes that northern and southern part of western Saudi Arabia are more prone to higher seismic risks compared to central coastal areas. A detailed seismic risk assessment based on site response analysis is recommended for whole coastal regions. The top priority shall be given to northern and southern coastal regimes. This detailed risk assessment will facilitate qualitative decision making for redundant industrial systems and post-earthquake recovery plans.

Acknowledgments The authors gratefully appreciate the support by Deanship of graduate studies and Geophysics Department, at King Abdulaziz University. The authors would also like to thank Dr. Abduallah M. S. Al-Amri for his assistance and cooperation in providing scientific data. Finally the authors would profoundly like to thank Earthquake Monitoring Center, Sultan Qaboos University, Oman, who graciously granted us permission to run EZ-FRISK software for academic purposes and scientific cooperation.

Open Access This article is distributed under the terms of the Creative Commons Attribution 4.0 International License (http://crea tivecommons.org/licenses/by/4.0/), which permits unrestricted use, distribution, and reproduction in any medium, provided you give appropriate credit to the original author(s) and the source, provide a link to the Creative Commons license, and indicate if changes were made.

\section{References}

Abrahamson NA, Bommer JJ (2005) Probability and uncertainty in seismic hazard analysis. Earthq Spectra 21(2):603-607

Abrahamson N, Silva W (1997) Empirical response spectral attenuation relations for shallow crustal earthquakes. Seismol Res Lett 68(1):94-127

Al-Amri AM (2013) Seismotectonics and seismogenic source zones of the Arabian Platform. In: Lithosphere dynamics and sedimentary basins: the Arabian plate and analogues. Springer, Berlin pp 295-316

Al-Arifi NS, Fat-Helbary R, Khalil AR, Lashin AA (2013) A new evaluation of seismic hazard for the northwestern part of Saudi Arabia. Nat Hazards 69(3):1435-1457

Al-Damegh K, Sandvol E, Barazangi M (2005) Crustal structure of the Arabian plate: new constraints from the analysis of teleseismic receiver functions. Earth Planet Sci Lett 231(3):177-196

Almadani S, Al-Amri A, Fnais M, Abdelrahman K, Ibrahim E, Abdelmoneim E (2015) Seismic hazard assessment for Yanbu metropolitan area, western Saudi Arabia. Arab J Geosci 8(11):9945-9958

Al-Malki M, Al-Amri A (2013) Seismic zones regionalization and hazard assessment of SW Arabian Shield and Southern Red Sea
Region. In: Lithosphere dynamics and sedimentary basins: the Arabian Plate and analogues. Springer, pp 317-331

Ambraseys N (2009) Earthquakes in the Mediterranean and Middle East, vol 8. Cambridge University Press, New York, pp 4333-4355

Ambraseys N, Melville C, Adams R (1995) The seismicity of Egypt, Arabia and the Red Sea. In: Ambraseys NN, Melville CP, Adams RD (eds) The seismicity of Egypt, Arabia and the Red Sea, vol. 1. Cambridge University Press, Cambridge, UK, p 201. ISBN 0521391202

Ambraseys NN, Simpson KU, Bommer JJ (1996) Prediction of horizontal response spectra in Europe. Earthq Eng Struct Dyn 25(4):371-400

Ambraseys N, Douglas J, Sarma S, Smit P (2005a) Equations for the estimation of strong ground motions from shallow crustal earthquakes using data from Europe and the Middle East: horizontal peak ground acceleration and spectral acceleration. Bull Earthq Eng 3(1):1-53

Ambraseys NN, Melville CP, Adams RD (2005b) The seismicity of Egypt, Arabia and the Red Sea: a historical review. Cambridge University Press, New York

Ares AF (2010) Development of probabilistic seismic hazard analysis for international sites, challenges and guidelines. In: 2010 1st International proceedings of the nuclear \& renewable energy conference (INREC). IEEE, Piscataway, pp 1-6

Atkinson GM, Boore DM (1995) Ground-motion relations for eastern North America. Bull Seismol Soc Am 85(1):17-30

Badawy A (1999) Historical seismicity of Egypt. Acta Geod Geophys Hung 34(1-2):119-135

Bommer JJ (2002) Deterministic vs. probabilistic seismic hazard assessment: an exaggerated and obstructive dichotomy. J Earthq Eng 6(S1):43-73

Bommer JJ, Scherbaum F (2008) The use and misuse of logic trees in probabilistic seismic hazard analysis. Earthq Spectra 24(4):997-1009

Boore DM, Joyner WB, Fumal TE (1997) Equations for estimating horizontal response spectra and peak acceleration from western North American earthquakes: a summary of recent work. Seismol Res Lett 68:128-153

Burkhard M, Grünthal G (2009) Seismic source zone characterization for the seismic hazard assessment project PEGASOS by the Expert Group 2 (EG1b). Swiss J Geosci 102(1):149-188

Campbell (2005) Overview of seismic PHSA approaches with emphasis on the management of uncertainties. In: 2 nd workshop on earthquake engineering for nuclear facilities: uncertainties in seismic hazard

Campbell KW, Bozorgnia Y (2003) Updated near-source groundmotion (attenuation) relations for the horizontal and vertical components of peak ground acceleration and acceleration response spectra. Bull Seismol Soc Am 93(1):314-331

Campbell KW, Bozorgnia Y (2008) NGA ground motion model for the geometric mean horizontal component of PGA, PGV, PGD and $5 \%$ damped linear elastic response spectra for periods ranging from 0.01 to $10 \mathrm{~s}$. Earthq Spectra 24(1):139-171

Cotton F, Scherbaum F, Bommer JJ, Bungum H (2006) Criteria for selecting and adjusting ground-motion models for specific target regions: application to central Europe and rock sites. J Seismol 10(2):137-156

Deif A, Nofal H, Elenean KA (2009) Extended deterministic seismic hazard assessment for the Aswan High Dam, Egypt, with emphasis on associated uncertainty. J Geophys Eng 6(3):250

Deif A, El-Hussain I, Al-Jabri K, Toksoz N, El-Hady S, Al-Hashmi S, Al-Toubi K, Al-Shijbi Y, Al-Saifi M (2013) Deterministic seismic hazard assessment for Sultanate of Oman. Arab J Geosci 6(12):4947-4960 
Dowrick D (2009) Seismic hazard assessment: earthquake resistant design and risk reduction, 2nd edn. Wiley, New York, pp 45-129

Fnais M, Abdelrahman K, E-Hady S, Abdel-monem E (2013) Seismicity and seismotectonics of the Jeddah area, Saudi Arabia. Earthq Resist Eng Struct IX 132:219

Gettings ME, Blank HR, Mooney WD, Healey JH (1986) Crustal structure of southwestern Saudi Arabia. J Geophys Res 91(B6):6491-6512

Guidoboni E, Comastri A (2005) Catalogue of Earthquakes and Tsunamis in the Mediterranean Area from the 11th to the 15th Century. Istituto nazionale di geofisica e vulcanologia

Guidoboni E, Comastri A, Traina G (1994) Catalogue of ancient earthquakes in the Mediterranean area up to the 10th Century, Vol 1. SGA

Gupta I (2002) The state of the art in seismic hazard analysis. ISET J Earthq Technol 39(4):311-346 (Paper, No. 428)

Gupta S, Kumar S, Wason H, Das R (2012) A statistical analysis of completeness of earthquake data around Dehradun city and its implications for seismicity evaluation. In: 15WCEE (Accepted)

Gutenberg B, Richter CF (1944) Frequency of earthquakes in California. Bull Seismol Soc Am 34(4):185-188

Hashemi M, Alesheikh AA, Zolfaghari MR (2013) A spatio-temporal model for probabilistic seismic hazard zonation of Tehran. Comput Geosci 58:8-18

Joyner WB, Boore DM (1981) Peak horizontal acceleration and velocity from strong-motion records including records from the 1979 Imperial Valley, California, earthquake. Bull Seismol Soc Am 71(6):2011-2038

Kijko A (2004) Estimation of the maximum earthquake magnitude $M_{\text {max }}$. Pure Appl Geophys 161(8):1655-1681

Kijko A, Sellevoll M (1989) Estimation of earthquake hazard parameters from incomplete data files. Part I. Utilization of extreme and complete catalogs with different threshold magnitudes. Bull Seismol Soc Am 79(3):645-654

Kijko A, Sellevoll MA (1992) Estimation of earthquake hazard parameters from incomplete data files. Part II. Incorporation of magnitude heterogeneity. Bull Seismol Soc Am 82(1):120-134

Leonard M, Clark D, Collins C, McPherson A (2011) The 2012 Australian seismic hazard map-source zones and parameterisation. In: Proceedings of the 2011 Australian earthquake engineering society conference, Barossa Valley, SA (this volume)

Lin T, Baker J (2011) Probabilistic seismic hazard deaggregation of ground motion prediction models. In: Proceedings of the 5th International conference on earthquake geotechnical engineering, Santiago, Chile, p 12

Meletti C, Galadini F, Valensise G, Stucchi M, Basili R, Barba S, Vannucci G, Boschi E (2008) A seismic source zone model for the seismic hazard assessment of the Italian territory. Tectonophysics 450(1):85-108

Mignan A, Woessner J (2012) Estimating the magnitude of completeness for earthquake catalogs. Community online resource for statistical seismicity analysis. pp 1-45. http:// www.corssa.org/export/sites/corssa/.galleries/articles-pdf/ Mignan-Woessner-2012-CORSSA-Magnitude-of-complete ness.pdf

Mohamed AE-EA, El-Hadidy M, Deif A, Elenean KA (2012) Seismic hazard studies in Egypt. NRIAG J Astron Geophys 1(2):119-140

Mokhtar T (2004) Variations of the crustal structure of Arabia. J King Abdulaziz Univ Earth Sci 15:1-27

Mokhtar T, Ammon C, Herrmann R, Ghalib H (2001) Surface wave velocities across Arabia. In: Monitoring the comprehensive nuclear-test-ban treaty: surface waves. Springer, pp 1425-1444
Pailoplee S, Sugiyama Y, Charusiri P (2010) Probabilistic seismic hazard analysis in Thailand and adjacent areas by using regional seismic source zones. Terr Atmos Ocean Sci 21(5):757-766

Peruš I, Fajfar P (2009) How reliable are the ground motion prediction equations? In: Proceedings of the 20th international conference on structural mechanics in reactor technology (SMiRT 20), Espoo, Paper, p 9

Poirier J, Taher M (1980) Historical seismicity in the near and Middle East, North Africa, and Spain from Arabic documents (VIIthXVIIIth century). Bull Seismol Soc Am 70(6):2185-2201

Re M (2000) Natural catastrophes-the current position, special millennium issue. Munich Reinsurance Co, Munich

Rehman F (2016) Assessment of seismic hazard by microzonation in Bahra area, Wadi Fatima, Kingdom of Saudi Arabia. (unpublished doctoral dissertation), King Abdulaziz University, Jeddah, Saudi Arabia

Rodgers AJ, Walter WR, Mellors RJ, Al-Amri AM, Zhang Y-S (1999) Lithospheric structure of the Arabian shield and platform from complete regional waveform modelling and surface wave group velocities. Geophys J Int 138(3):871-878

Sabetta F, Pugliese A (1987) Attenuation of peak horizontal acceleration and velocity from Italian strong-motion records. Bull Seismol Soc Am 77(5):1491-1513

Sadigh K, Chang C-Y, Egan J, Makdisi F, Youngs R (1997) Attenuation relationships for shallow crustal earthquakes based on California strong motion data. Seismol Res Lett 68(1):180-189

Smith RP, Jackson SM, Hackett WR (1996) Paleoseismology and seismic hazards evaluations in extensional volcanic terrains. J Geophys Res 101(B3):6277-6292

Stepp JC, Wong I, Whitney J, Quittmeyer R, Abrahamson N, Toro G, Youngs R, Coppersmith K, Savy J, Sullivan T (2001) Probabilistic seismic hazard analyses for ground motions and fault displacement at Yucca Mountain, Nevada. Earthq Spectra 17(1):113-151

Stern RJ, Johnson PR (2008) Do variations in Arabian plate lithospheric structure control deformation in the ArabianEurasian convergence zone? In: Proceedings IOP conference series: earth and environmental science, vol 2. IOP Publishing, p 012005

Stern RJ, Johnson P (2010) Continental lithosphere of the Arabian Plate: a geologic, petrologic, and geophysical synthesis. Earth Sci Rev 101(1-2):29-67

Tavakoli H, Amiri MT, Abdollahzade G, Janalizade A (2013) Probabilistic and deterministic seismic hazard assessment: a case study in Babol, pp 265-270

Vipin K, Sitharam T (2013) Delineation of seismic source zones based on seismicity parameters and probabilistic evaluation of seismic hazard using logic tree approach. J Earth Syst Sci 122(3):661-676

Waseem M, Khan MA, Javed MW, Ali SM (2013) Deterministic seismic hazard analysis for Peshawar, Pakistan. J Himal Earth Sci 46(1):67-72

Wiemer S, Wyss M (2000) Minimum magnitude of completeness in earthquake catalogs: examples from Alaska, the western United States, and Japan. Bull Seismol Soc Am 90(4):859-869

Woessner J, Wiemer S (2005) Assessing the quality of earthquake catalogues: estimating the magnitude of completeness and its uncertainty. Bull Seismol Soc Am 95(2):684-698

Yazdani A, Kowsari M (2013) Earthquake ground-motion prediction equations for northern Iran. Nat Hazards 69(3):1877-1894 